\title{
19. MOLECULAR COMPOSITION AND DIAGENESIS OF ORGANIC MATTER (GEOLIPIDS) IN SEDIMENTS FROM SITES 677 AND 678, LEG 111
}

\author{
Ryoshi Ishiwatari, ${ }^{2}$ Shuichi Yamamoto, ${ }^{3}$ and Tsutomu Machihara ${ }^{4}$
}

\begin{abstract}
The results of a preliminary organic analysis conducted on sediment samples from Sites 677 and 678, ODP Leg 111, indicate that the lipids are derived mainly from marine organisms, with bacterially-derived lipids. Terrestrial higher plant wax residues exist only in trace amounts. Diagenesis of organic matter by thermal stress is not extensive at either site.
\end{abstract}

\section{INTRODUCTION}

Sites 677 and 678 of Ocean Drilling Program (ODP) Leg 111 are about $200 \mathrm{~km}$ south of the spreading axis of the Costa Rica Rift, in the eastern equatorial Pacific. The remote sites are about $400 \mathrm{~km}$ from the terrigenous influence of the Ecuador coast.

Because Site 677 is on a local minimum heatflow area and Site 678 is on a local maximum, sediments at the two sites were subject to different degrees of thermal stress resulting from varying geothermal heat flow. Therefore, it is of interest to examine whether the different regimes of geothermal heat flow at the two sites caused differences in the sedimentary organic matter. Whelan and Hunt (1983) characterized the sedimentary organic matter at nearby Deep Sea Drilling Project Sites 504 and 505 by a thermal analysis-gas chromatography technique, from which they recognized different degrees of thermal hydrocarbon generation resulting from the thermal differences between the two sites. No lipid analysis has been conducted on sediments in this area.

As a preliminary study, we conducted lipid analysis on sediment samples from Sites 677 and 678 to determine the nature and source of the sedimentary organic matter and to examine maturation effects on the composition of the sedimentary organic matter.

\section{EXPERIMENTAL METHODS}

We analyzed four core samples from Site 677 and two core samples from Site 678 (Table 1). The samples were freeze-dried and then saponified with $1 \mathrm{~N} \mathrm{KOH}$ in methanol under reflux for $3 \mathrm{hr}$. After centrifugation the supernatant was transferred to a separatory funnel and extracted with $n$-hexane/ether (9:1). The $n$-hexane/ether extract was washed with distilled water, dried with anhydrous $\mathrm{Na}_{2} \mathrm{SO}_{4}$ concentrated by rotary evaporation, and subjected to thin-layer chromatography to isolate hydrocarbons and alcohols (including sterols). The thin-layer plate (Whatman, silica gel PLK5F) was pre-eluted with $n$-hexane/ether (9:1) and developed with $n$-hexane/ethyl acetate (7:3). The alcohol fraction was silylated prior to analysis.

Gas chromatography-mass spectrometry was conducted using a Varian 3700 gas chromatograph, equipped with a UP- 2 column ( $25 \mathrm{~m}$ long, $0.25 \mathrm{~mm}$ i.d.), connected to a Finnigan INCOS 50 quadrupole mass spectrometer. Typically, splitless injection of samples at $300^{\circ} \mathrm{C}$ was employed with the gas chromatograph programmed from $50^{\circ}$ to $120^{\circ} \mathrm{C}$ at a

\footnotetext{
${ }^{1}$ Becker, K., Sakai, H., et al., 1989. Proc. ODP, Sci. Results, 111: College Station, TX (Ocean Drilling Program).

2 Department of Chemistry, Faculty of Science, Tokyo Metropolitan University, Setagaya, Tokyo 158, Japan.

3 Department of Education, Soka University, Hachioji, Tokyo 192, Japan.

4 Technology Research Center, Japan National Oil Corporation, Hamura-cho, Nishitama-gun, Tokyo 190-11, Japan.
}

Table 1. Description of samples from Sites 677 and 678.

\begin{tabular}{|c|c|c|c|c|}
\hline $\begin{array}{l}\text { Core, section, } \\
\text { interval }(\mathrm{cm})\end{array}$ & $\begin{array}{l}\text { Depth } \\
\text { (mbsf) }\end{array}$ & Age & $\begin{array}{l}\text { Total organic } \\
\text { carbon (wt } \% \text { ) }\end{array}$ & $\begin{array}{c}\text { Calcium carbonate } \\
(\mathrm{wt} \%)\end{array}$ \\
\hline \multicolumn{5}{|c|}{ Hole $677 \mathrm{~A}\left(1^{\circ} 12.138^{\prime} \mathrm{N}, 83^{\circ} 44.220^{\prime} \mathrm{W}\right.$; water depth $\left.3472.3 \mathrm{~m}\right)$} \\
\hline $1 H-4,52-56$ & 4.5 & Pleistocene & 0.58 & 21.19 \\
\hline $13 \mathrm{H}-4,34-38$ & 116.7 & late Pliocene & 0.22 & 62.97 \\
\hline $20 \mathrm{X}-3,48-52$ & 179.2 & early Pliocene & 0.33 & 98.10 \\
\hline $33 X-2,102-106$ & 304.6 & late Miocene & 0.12 & 64.10 \\
\hline \multicolumn{5}{|c|}{ Hole $678 \mathrm{~B}\left(1^{\circ} 13.006^{\prime} \mathrm{N}, 83^{\circ} 43.392^{\prime} \mathrm{W}\right.$; water depth $\left.3446.8 \mathrm{~m}\right)$} \\
\hline $1 \mathrm{H}-4,34-38$ & 0.5 & Pleistocene & 0.69 & 40.32 \\
\hline $3 \mathrm{H}-4,33-38$ & 99.7 & Pliocene & 0.50 & 40.27 \\
\hline
\end{tabular}

Note: Data from Shipboard Scientific Party (1988).

rate of $30^{\circ} \mathrm{C} / \mathrm{min}$ and then from $120^{\circ}$ to $300^{\circ} \mathrm{C}$ at a rate of $6^{\circ} \mathrm{C} / \mathrm{min}$ and held isothermally at $300^{\circ} \mathrm{C}$ for $60 \mathrm{~min}$. The mass spectrometer was operated at an ionization energy at $70 \mathrm{eV}$, with a cycle time of $1.5 \mathrm{~s}$ and a mass range of 50-650 daltons.

Compounds were identified by mass spectral interpretation, retention data, consideration of elution orders, and comparison of spectra with those of standards (e.g., Lee et al., 1979). Mass fragmentography was used extensively to aid in homologous compound identification.

\section{RESULTS AND DISCUSSION}

The sediments from the high heatflow area at Site 678 and those from the low heatflow area at Site 677 have similar characteristics (Table 1). Sediments from Site 677 are mostly calcareous nannofossil oozes (Samples 111-677A-1H-4, 52-56 cm, and 111-677A-13H-4, 34-38 cm), siliceous nannofossil ooze and chalk (111-677A-20X-3, 48-52 cm), and cherty limestone and nannofossil chalk (111-677A-33X-2, 102-106 cm).

\section{Geolipid Analyses}

The $n$-alkanes of the samples range from $\mathrm{C}_{14}$ to $\mathrm{C}_{33}$ and exhibit an essentially bimodal distribution, with maxima at $\mathrm{C}_{17}$ and $C_{22}$. Most of the samples have a third maximum at $C_{29}$, in a range from $\mathrm{C}_{25}$ to $\mathrm{C}_{35}$, with odd carbon numbers predominating over even ones. CPI (even-to-odd ratio) values calculated for the $n$-alkanes $\mathrm{C}_{24}-\mathrm{C}_{34}$ range from 1.4 to 2.6 . Figure 1 shows the relative abundances of $n$-alkanes in the sediment samples.

The $n$-alkane distribution patterns probably indicate an origin from both degraded algae and bacteria (Simoneit, 1978b, 1981). Although the gas chromatography data are not presented in this paper, a series of cycloalkanes (alkylcyclohexanes and alkylcyclopentanes) was found in considerable amounts. The $n$ alkanes larger than $\mathrm{C}_{25}$ are associated with higher plant wax (Simoneit et al., 1984). Detection of a trace amount of pristane but no phytane indicates a highly oxic sedimentary paleoenviron- 


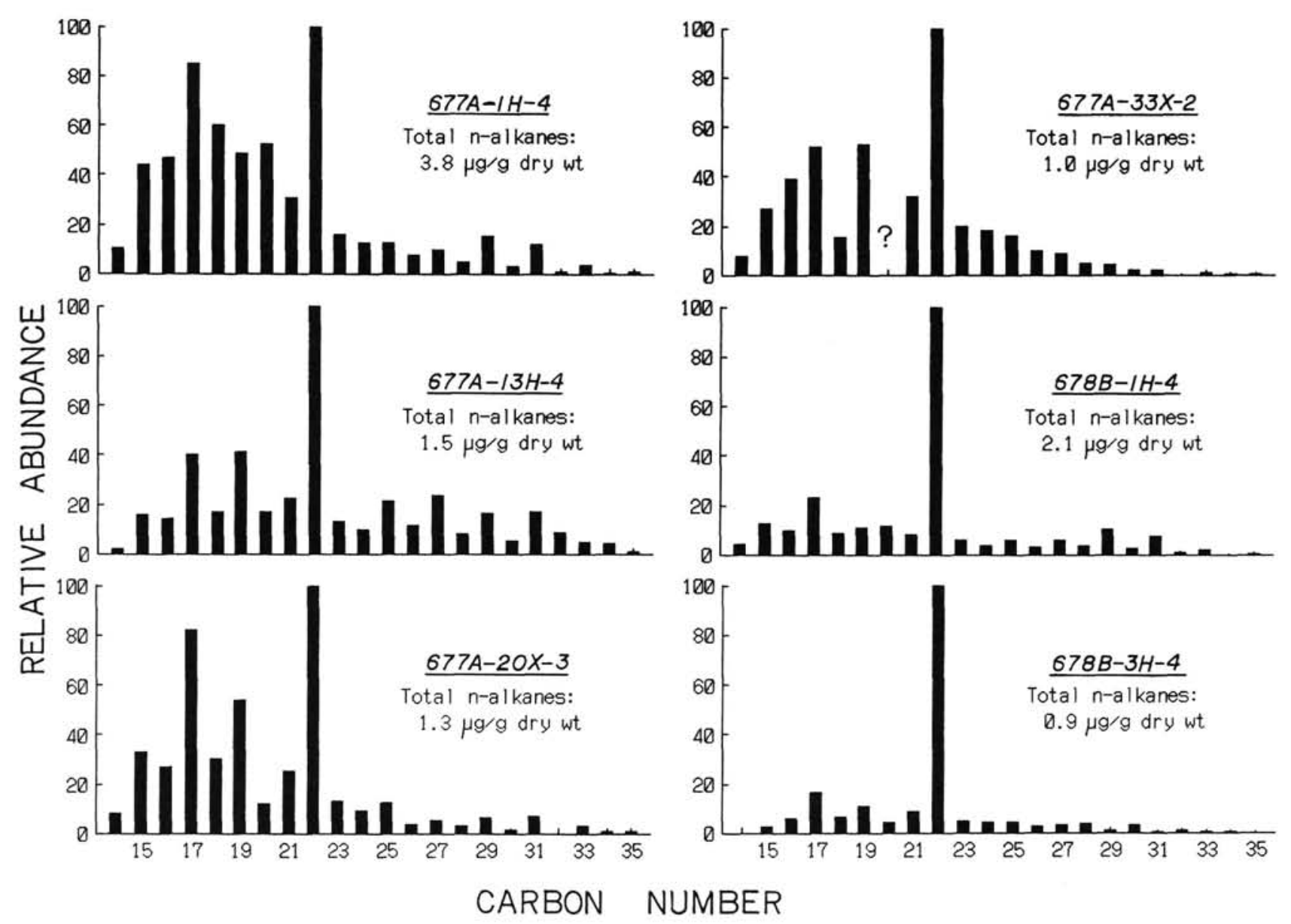

Figure 1. Relative abundances of $n$-alkanes in sediments from Sites 677 and 678 .

ment at both sites (Didyk et al., 1978). Steranes and triterpanes were found in trace amounts, but it is not clear whether these compounds are indigenous or reworked. The origin of $n-C_{22}$ alkane, which is dominant for all samples examined, is not known. Similar $n$-alkane distributions have been reported for some Black Sea sediments (Simoneit, 1978b).

The $n$-alcohols of the samples range from $\mathrm{C}_{12}$ to $\mathrm{C}_{30}$, with a strong even carbon number predominance over odd numbers and maxima at $\mathrm{C}_{18}$ or $\mathrm{C}_{22}$. CPI values calculated for $n$-alcohols from $\mathrm{C}_{13}$ to $\mathrm{C}_{19}$ range from 7.4 to 13.5 , and those for $\mathrm{C}_{21}-\mathrm{C}_{27}$ alcohols range from 5.2 to 8.6. Phytol is abundant only in the uppermost samples and is probably derived from phytoplanktonic chlorophylls. The $n$-alkanol homologues shorter than $\mathrm{C}_{20}$ are probably autochthonous, and those longer than $\mathrm{C}_{22}$ are derived from higher plant waxes (Cranwell and Volkman, 1981).

Several features are notable in the sterol distribution. Figure 2 shows typical examples of partial gas chromatograms of sterols (TMS ethers) from the sediment samples. Cholest-5-en-3 $\beta$-ol (G, Fig. 2) is the major sterol, while cholesta-5,22E-dien-3 $\beta$-ol (E) and 24-methylcholesta-5,22E-dien-3 $\beta$-ol (I) are the second most important sterols. The sterol 24-ethylcholest-5-en-3 $\beta$-ol (U $=\mathrm{C}_{29}$-sterol), which has been used as an indicator of terrestrial input, is not an abundant component (Volkman, 1986). Also present is $4 \alpha, 23,24$-trimethyl- $5 \alpha(\mathrm{H})$-cholest-22-en-3 $\beta$-ol $(\mathrm{a}=$ dinosterol), which is related to an input of dinoflagellates (e.g., Boon et al., 1979).

\section{Sources of Organic Matter}

The distributions of hydrocarbons, $n$-alcohols, and sterols are essentially the same between Sites 677 and 678. The molecu- lar composition of the geolipids indicates that the organic matter in the sediments is of mixed marine (microbial) and terrigenous origin, with the former probably predominant over the latter.

\section{Diagenesis of Organic Matter}

In general, sedimentary organic matter undergoes alteration under the influences of thermal stress. Thermal stress is expected to affect alcohols and sterols more extensively than hydrocarbons, because alcohols and sterols are comparatively chemically less stable. Diagenesis of sterols would involve hydrogenation of sterols to stanols in sediments, transformation of stanols into sterenes, and hydrogenation to saturated steranes or dehydrogenation to aromatic steroid hydrocarbons (Rullkötter and Welte, 1983).

Ratios of $5 \alpha(\mathrm{H})$-stanol $/ \Delta^{5}$-stenol $(\mathrm{F} / \mathrm{E}, \mathrm{H} / \mathrm{G}$, and J/I, Fig. 2) are approximately 0.3 for the uppermost sediment layers, which is within the range often observed for marine sediments. The increasing trend of this ratio with depth is not obvious. Therefore, a progressive conversion from $\Delta^{5}$-stenols to $5 \alpha(\mathrm{H})$ stanols in sediments is not clear. Phytol was observed only in the upper $0.5 \mathrm{~m}$ of sediment at Site 678 (Sample 111-678B-1H-4, $52-56 \mathrm{~cm}$ ), whereas it was detected in the sediments above 179 $\mathrm{m}$ below the seafloor at Site 677 (Sample 111-677A-13H-4, 34$38 \mathrm{~cm}$ ). This distribution indicates that phytol is diagnentically unstable (deLeeuw et al., 1977). No marked vertical trends of $n$ alcohol and hydrocarbon composition were observed.

The preceding results indicate that the influence of thermal stress on the alteration of organic matter is minor in the cored sediments at both sites. If sedimentary organic matter were subject to strong thermal stress, we should have observed hydrogen- 


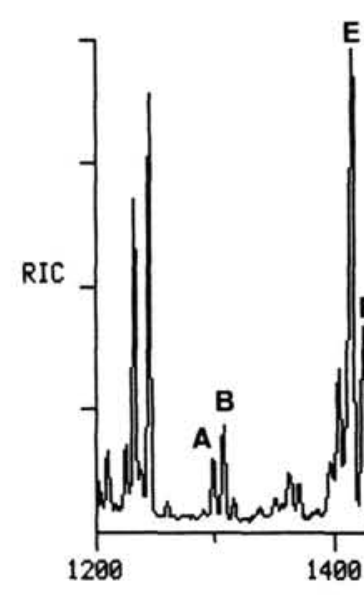

$\int^{\mathbf{E}} \mid$
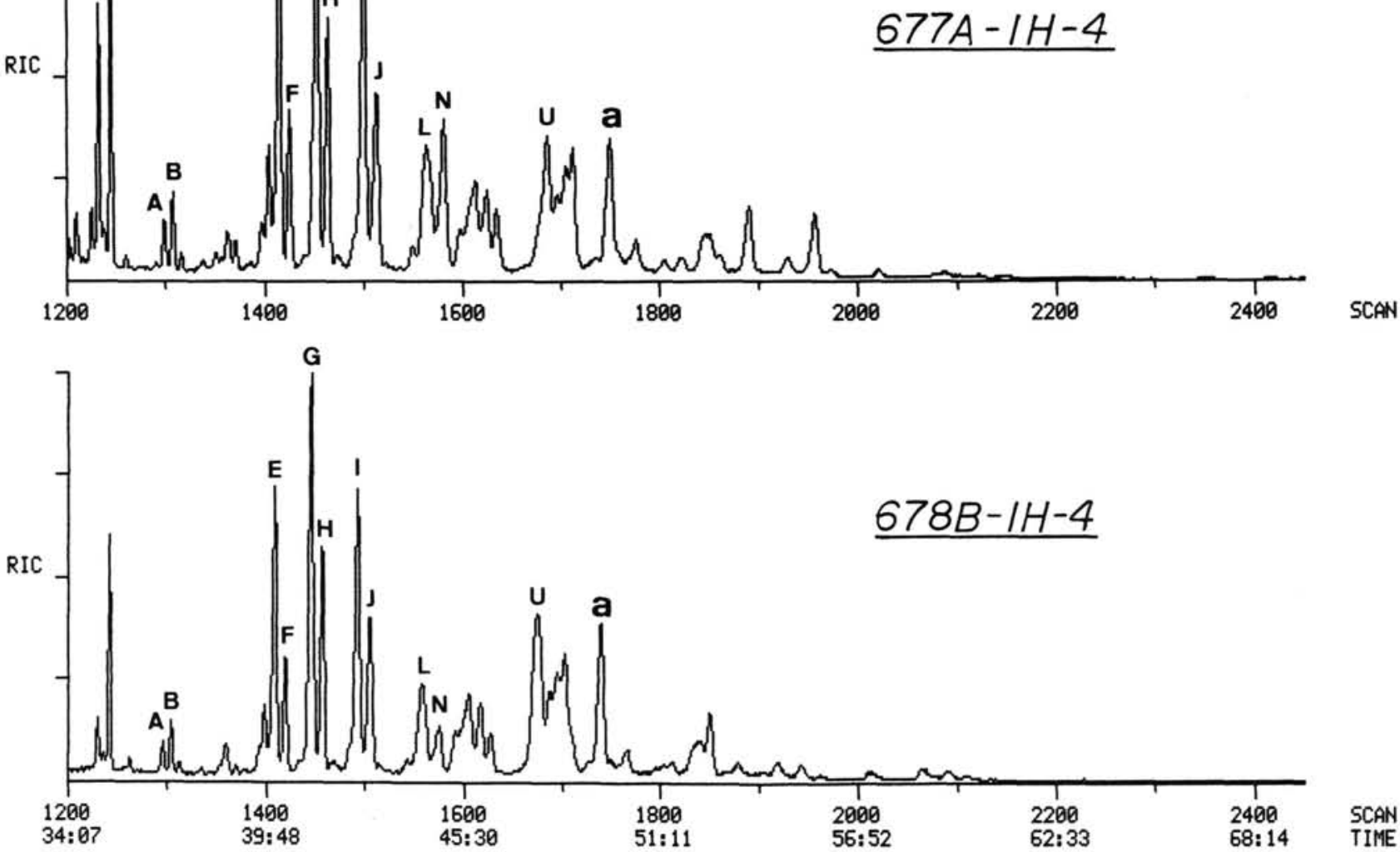

Figure 2. Typical examples of partial gas chromatograms of sterols (TMS ethers) from sediment samples. $\mathrm{A}=24$-norcholesta-5,22E-dien-3 $\beta$ ol; $\mathrm{B}=24$-norcholest-22E-en-3 $\beta$-ol; $\mathrm{E}=$ cholesta-5,22E-dien-3 $\beta$-ol (22-dehydrocholesterol); $\mathrm{F}=5 \alpha(\mathrm{H})$-cholest-22E-en-3 $\beta$-ol; $\mathrm{G}=$ cholest5-en-3 $\beta$-ol (cholesterol); $\mathrm{H}=5 \alpha(\mathrm{H})$-cholestan-3 $\beta$-ol (cholestanol); I $=24$-methylcholesta-5,22E-dien-3 $\beta$-ol (brassicasterol); J $=24$-methyi-

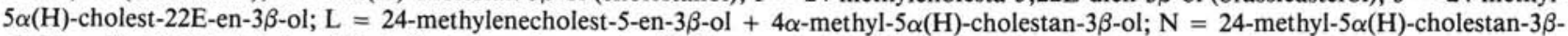
ol; $\mathrm{U}=24$-ethylcholest-5-en-3 $\beta$-ol ( $\beta$-citosterol); $\mathrm{a}=4 \alpha, 23,24$-trimethyl-5 $\alpha(\mathrm{H})$-cholest-22-en-3 $\beta$-ol (dinosterol).

ation and/or aromatization of steroid compounds. However, only trace amounts of steroidal hydrocarbons were detected in these sediments, and no aromatized steroid hydrocarbons were detected; thermal conversion to steroidal hydrocarbons was not widespread.

\section{CONCLUSIONS}

The geolipids in sediment samples from Sites 677 and 678 are primarily autochthonous and of marine origin (microbially derived), with traces of terrestrial higher plant wax residues.

Diagenesis of the organic matter by thermal stress is not extensive at either site. The only effect of different geothermal stresses in this area is reflected by the phytol concentrations in the sediments. No marked vertical changes in $n$-alcohol and hydrocarbon compositions were observed.

\section{ACKNOWLEDGMENTS}

Partial financial assistance from JNOC (SIGMA research project) is gratefully acknowledged.

\section{REFERENCES}

Boon, J. J., Rijpstra, W.I.C., de Lange, F., and deLeeuw, J. W., 1979. Black Sea sterol: a molecular fossil for dinoflagellate blooms. $\mathrm{Na}$ ture, 277:125-127.

Cranwell, P. A., and Volkman, J. K., 1981. Alkyl and steryl esters in a Recent lacustrine sediment. Chem. Geol., 32:29-43.
deLeeuw, J. W., Simoneit, B.R.T., Boon, J. J., Rijpstra, W.I.C., deLange, F., van der Leeden, J.C.W., Corriea, V. A., Burlingame, A. L., and Schenck, P. A., 1977. Phytol-derived compounds in the geosphere. Adv. Org. Geochem. Proc. Int. Meet. 7th, 1975, 61-79.

Didyk, B. M., Simoneit, B.R.T., Brassel, S. C., and Eglinton, G., 1978. Organic geochemical indicators of palaeoenvironmental conditions of sedimentation. Nature, 272:216-222.

Lee, C., Farrington, J. W., and Gagosian, R. B., 1979. Sterol geochemistry of sediments from the western North Atlantic Ocean and adjacent coastal areas. Geochim. Cosmochim. Acta, 43:35-46.

Rullkötter, J., and Welte, D. H., 1983. Maturation of organic matter in areas of high heat flow: a study of sediments from DSDP Leg 63, offshore California, and Leg 64, Gulf of California. Adv. Org. Geochem. Proc. Int. Meeting 10th, 1981 (1983), 438-448.

Shipboard Scientific Party, 1988. Sites 677 and 678. In Becker, K., Sakai, H., et al., Proc. ODP, Init. Repts., 111: College Station, TX (Ocean Drilling Program), 253-346.

Simoneit, B.R.T., 1978a. The organic chemistry of marine sediments. In Riley, J. P., and Chester, R. (Eds.), Chemical Oceanography (vol. 7) (2nd ed.): New York (Academic Press), 233-311.

$1978 \mathrm{~b}$. Organic geochemistry of terrigenous muds and various shales from the Black Sea, DSDP Leg 42B. In Ross, D. A., Neprochnov, Y. P., et al., Init. Repts. DSDP, 42: Washington (U.S. Govt. Printing Office), 749-753.

1981. Utility of molecular markers and stable isotope compositions in the evaluation of sources and diagenesis of organic matter in the geosphere. In Prashnowsky, A. A. (Ed.), The Impact of the Treibs' Porphyrin Concept on the Modern Organic Geochemistry: Wurzburg (Bayerische Julius Maximilian Univ.), 133-158. 
Simoneit, B.R.T., Philp, R. P., Jenden, P. D., and Galimov, E. M., 1984. Organic geochemistry of Deep Sea Drilling Project sediments from the Gulf of California: hydrothermal effects on unconsolidated diatom ooze. Org. Geochem., 7:173-205.

Volkman, J. K., 1986. A review of sterol markers for marine and terrigenous organic matter. Org. Geochem., 9:83-100.

Whelan, J. K., and Hunt, J. M., 1983. Organic matter in Deep Sea Drilling Project Site 504 and 505 sediments studied by a thermal analysis-gas chromatography technique. In Cann, J. R., Langseth, M. G., Honnorez, J., Von Herzen, R. P., White, S. M., et al., Init. Repts. DSDP, 69: Washington (U.S. Govt. Printing Office), 443450.

Date of initial receipt: 30 May 1988 Date of acceptance: 15 December 1988 Ms 111B-152 